WSRC-TR-2001-00372, Rev. 0

Keywords: Waste processing, cesium High Activity Waste

Retention: Permanent

\title{
DEMONSTRATION OF CAUSTIC-SIDE SOLVENT EXTRACTION WITH SAVANNAH RIVER SITE HIGH-LEVEL WASTE: RESULTS OF ORGANIC AND TRACE COMPONENT ANALYSES
}

\author{
S. L. Crump \\ M. A. Norato \\ R. A. Pierce \\ R. J. Ray \\ D. D. Walker \\ T. L. White
}

December 7, 2001

Westinghouse Savannah River Company

Savannah River Technology Center

Aiken, SC 29808

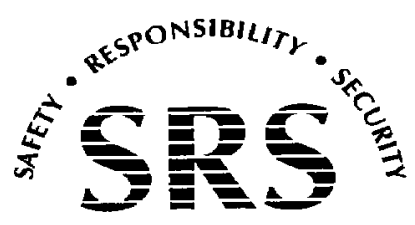


This document was prepared in conjunction with work accomplished under Contract No. DE-AC09-96SR18500 with the U.S. Department of Energy

\section{DISCLAIMER}

This report was prepared as an account of work sponsored by an agency of the United States Government. Neither the United States Government nor any agency thereof, nor any of their employees, makes any warranty, express or implied, or assumes any legal liability or responsibility for the accuracy, completeness, or usefulness of any information, apparatus, product or process disclosed, or represents that its use would not infringe privately owned rights. Reference herein to any specific commercial product, process or service by trade name, trademark, manufacturer, or otherwise does not necessarily constitute or imply its endorsement, recommendation, or favoring by the United States Government or any agency thereof. The views and opinions of authors expressed herein do not necessarily state or reflect those of the United States Government or any agency thereof.

This report has been reproduced directly from the best available copy.

Available for sale to the public, in paper, from U.S. Department of Commerce, National Technical Information Service, 5285 Port Royal Road, Springfield, VA 22161

phone: (800) 553-6847

fax: (703) 605-6900

email: orders@ntis.fedworld.gov

online ordering: http://www.ntis.gov/support/index.html

Available electronically at http://www.osti.gov/bridge

Available for processing fee to U.S. Department of Energy and its contractors, in paper, from: U.S. Department of Energy, Office of Scientific and Technical Information, P.O. Box 62, Oak Ridge, TN 37831-0062, phone: (865) 576-8401, fax: (865) 576-5728, email: reports@adonis.osti.gov 
WSRC-TR-2001-00372, Rev. 0

Page 2 of 21

\section{REVIEWS AND APPROVALS}

\section{$\underline{\text { Authors }}$}

D. D. Walker Date

Savannah River Technology Center

T. L. White Date

Savannah River Technology Center

M. A. Norato

Date

Savannah River Technology Center

R. A. Pierce Date

Savannah River Technology Center

S. L. Crump

Date

R. J. Ray

Date

Savannah River Technology Center

Savannah River Technology Center

\section{$\underline{\text { Technical Review }}$}

W. R. Wilmarth Date

Savannah River Technology Center

\section{$\underline{\text { Approvals }}$}

M. C. Thompson, SRTC, TFA System Lead

Date

R. E. Edwards, Manager, HLW Process Engineering

Date

J. T. Carter, Director of Engineering, Salt Processing Project

Date

H. D. Harmon, TFA SPP Technology Development Manager

Date

W. D. Clark, DOE-SR, Technical Support Manager

Date

S. D. Fink, Manager, Liquid Waste Processing Group

Date

W. L. Tamosaitis, Manager, Waste Processing Technology Section

Date 


\section{CONTENTS}

SUMMARY

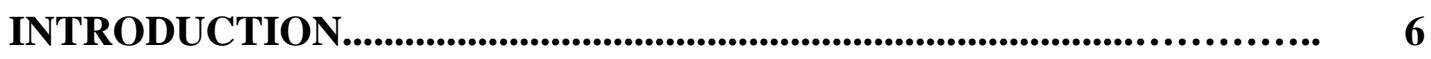

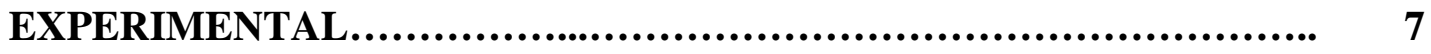

Tank 37H/44F Composite Waste Composition.................................... 7

Contactor Physical Configuration......................................... 9

Experimental Operations and Sampling Plan......................... 9

Solvent Entrainment and Composition Changes........................ 9

Minor Components................................................... 11

Analytical Methods................................................. 11

RESULTS AND DISCUSSION........................................... 13

Organic Compounds in the Tank 37H/44F Composite Waste........ 13

Solvent Entrainment................................................. 13

Solvent Composition Changes.......................................... 15

Minor Organic Compounds......................................... 16

Minor Inorganic Components........................................ 17

CONCLUSIONS............................................................................................ 20

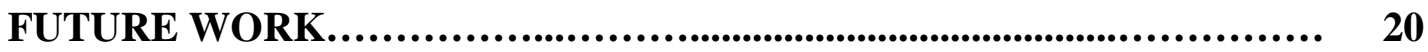

REFERENCES.......................................................... $\quad 21$ 
WSRC-TR-2001-00372, Rev. 0

Page 4 of 21

\section{LIST OF FIGURES}

Flow diagram and sampling points............................ 10

\section{LIST OF TABLES}

I Origin of Tank 37H/44F Composite Sample..................... 7

II Composition of the Tank 37H/44F Composite Sample........... 8

III Organic Compounds in the Tank 37H/44F Composite Sample... 13

IV Solvent Entrainment Estimated from Decanter Observations.... 14

V BOBCalixC6 and Cs7SB Modifier Concentrations in Process

Streams........................................................... 15

VI Solvent Composition Changes.................................... 16

VII Minor Organic Compounds........................................ 16

VIII Minor Inorganic Components..................................... 18

IX Uranium Concentrations in Process Streams...................... 19 


\section{SUMMARY}

Researchers at the Savannah River Technology Center (SRTC) successfully demonstrated the chemistry and process equipment of the Caustic-Side Solvent Extraction (CSSX) flowsheet for the decontamination of high-level waste using a 33-stage, 2-cm centrifugal contactor apparatus. This represents the first CSSX process demonstration using Savannah River Site (SRS) high-level waste solution. Three tests lasting 6, 12, and 48 hours processed simulated average SRS waste, simulated Tank 37H/44F composite waste, and Tank 37H/44F composite high-level waste, respectively. Researchers previously documented the contactor test results for hydraulic performance and cesium removal. ${ }^{1}$ This report details the results of analyses for organic compounds and trace components in various process streams based on samples from the 48-hour radioactive waste test.

Results of analyses for organic compounds and minor components in the various process streams do not indicate any problems with the viability of the process. Analyses of solvent components in the aqueous effluent streams (decontaminated waste, strip, and solvent wash) did not reveal significant amounts of carryover above the amounts determined by decanter measurements ( 0.01 to $0.37 \%$ ). Generally, organic compounds from the waste or from solvent decomposition were not found above detection limits in the solvent or aqueous streams $(<10 \mathrm{mg} / \mathrm{L})$. However, this result does not allow the conclusion that the waste compounds will not concentrate in process streams since the compounds were not detectable in the original waste solution $(<1000 \mathrm{mg} / \mathrm{L})$. The extraction solvent did not change significantly ( $<6 \%$ change in extractant or modifier), nor did it accumulate significant amounts of minor components (such as potassium, technetium-99, or uranium) during 25 solvent turnovers. Changes in sample preparation or analytical methods could improve results in future tests. 


\section{INTRODUCTION}

A solvent extraction process for removal of cesium from alkaline solutions has been developed utilizing a novel solvent invented at the Oak Ridge National Laboratory. ${ }^{2}$ This solvent consists of an extractant, calix [4]arene-bis-(tert-octylbenzo-crown-6)

(BOBCalixC6), dissolved in an inert hydrocarbon matrix. An alkylphenoxy alcohol modifier, 1-(2,2,3,3-tetrafluoropropoxy)-3-(4-sec-butylphenoxy)-2-propanol (Cs7SB modifier), is added to the solvent to enhance the extraction power of the calixarene and to prevent the formation of a third phase. An additional additive, trioctylamine, is used to improve stripping performance and to mitigate the effects of any surfactants present in the feed stream.

A number of laboratory studies with simulated wastes determined that the solvent system is stable and performs well in the presence of the major chemical components in the SRS high-level waste tanks. To proceed with the design of a CSSX plant for Cs removal from high-level waste, extended operation of a small process on actual SRS waste was required. Previous results with simulants ${ }^{3-4}$ required validation with Tank $37 \mathrm{H} / 44 \mathrm{~F}$ composite waste to ensure that no unexpected serious perturbation of the system behavior occurs due to the presence of minor components in the waste. These components might not have been present in adequate quantities in the simulated waste to affect test results.

Researchers completed the radioactive waste test in March 2001 and reported contactor hydraulic performance, cesium-removal results, and solvent carryover or entrainment measurements (from decanter data). ${ }^{1}$ This report summarizes results of analyses for organic compounds and inorganic components found in samples taken during the radioactive waste test. The purpose of these analyses was to determine whether minor components accumulate or how they distribute in the process streams. This included actinide elements, organic compounds, and minor waste components (such as $\mathrm{K}$, Al, and $\mathrm{Tc}$ ). These data also provide additional information on solvent carryover in aqueous process streams and compliments the decanter data reported previously.

This work fulfills a request from P. L. Rutland, Technical Task Request HLW-SDT-TTR2000-00010, August, 2000. The work complies with the following plan: R. A. Peterson, "Task Technical and Quality Assurance Plan for Solvent Extraction Real Waste Contactor Testing," WSRC-RP-2000-00889, Rev.0, April 30, 2001. The need for radioactive waste testing by SRTC is documented in the following work scope matrix: High-Level Waste Disposition Systems Engineering Team, Applied Technology Integration Scope of Work Matrix for Caustic-Side Solvent Extraction, HLW-SDT-200000051, Rev. 4, November 9, 2000. Requirements for the test are recorded in the following document: M. A. Nadeau, "Task Requirements and Criteria, Salt Waste Processing Facility, Real Waste Testing for the CSSX Alternative (U)," G-TC-A-00011, Rev. 2, March 1, 2001. 


\section{EXPERIMENTAL}

\section{Tank 37H/44F Composite Waste Composition}

SRS tank farm personnel provided samples of liquid radioactive waste from Tanks $37 \mathrm{H}$ and 44F. These tanks are currently inactive and store predominantly salt cake with a layer of concentrated salt solution. Portions of the supernatant liquid were obtained in $38-\mathrm{L}$ samplers. The samples were received, stored, and processed in a shielded facility at the SRTC. The two tank samples were combined in a loosely covered stainless steel tank. Table I summarizes source information for each sample.

The solution density was measured in 50-mL volumetric flasks and weighed on a balance sensitive to $\pm 1 \mathrm{mg}$. Unfiltered portions $(1 \mathrm{~mL})$ were diluted in 99 grams of water or 0.2 M nitric acid and sent to the SRTC Analytical Development Section for routine analyses. The exact dilution factors were calculated from the density, weight of the nominal 1-mL sample, and weight of the water, assuming ideal mixing of the waste and water

The sodium ion concentration of the as-received composite solution was approximately 12.5 M. However, during transfer of the solution between storage tanks, researchers discovered a mass of crystallized salt at the bottom of the tank. The crystallized material likely formed upon cooling after removal from the waste tanks. The waste tank temperatures are typically $35^{\circ} \mathrm{C}$ and the Shielded Cells are $\leq 25^{\circ} \mathrm{C}$. Approximately $10 \mathrm{~L}$ of water was added to dissolve the solids.

The solution of dissolved solids was added to the composite sample. A subsequent analysis indicated the sodium ion concentration remained approximately $12 \mathrm{M}$. A portion of the salt solution $(\sim 50 \mathrm{~L})$ was transferred to a new tank and was diluted with $2.0 \mathrm{M}$ $\mathrm{NaOH}$ solution $(\sim 85 \mathrm{~L})$ to achieve a final sodium ion concentration of 5.6 M. Table II lists the inorganic components found in the diluted salt solution.

Table I. Origin of Tank 37H/44F Composite Sample

\section{Source}

Date Sampled

Tank Farm Identification

Date received at SRTC

Approximate volume (L)
Tank 37H

$10 / 10 / 2000$

HTF-358

$10 / 12 / 00$

39
Tank 44F

9/27/2000

(no identification)

$9 / 28 / 00$

$32 *$

*The sampler contained $38 \mathrm{~L}$. Approximately $6 \mathrm{~L}$ were transferred to another program and the remainder $(32 \mathrm{~L})$ was combined with the Tank $37 \mathrm{H}$ sample. 
WSRC-TR-2001-00372, Rev. 0

Page 8 of 21

Table II. Composition of the Tank 37H/44F Composite Sample

\begin{tabular}{|l|l|}
\hline Component & $\begin{array}{l}\text { Concentration } \\
\text { (Molar) }\end{array}$ \\
\hline $\mathrm{Na}^{+}(\mathrm{M})$ & 5.61 \\
\hline $\mathrm{K}^{+}(\mathrm{M})$ & 0.037 \\
\hline $\mathrm{Rb}^{+}(\mathrm{mM})$ & 0.092 \\
\hline $\mathrm{Cs}^{+}(\mathrm{mM})$ & 0.17 \\
\hline & \\
\hline Free $\mathrm{OH}^{-}$ & 3.9 \\
\hline $\mathrm{NO}_{3}{ }^{-}$ & 0.65 \\
\hline $\mathrm{NO}_{2}^{-}$ & 0.51 \\
\hline $\mathrm{AlO}_{2}^{-}$ & 0.17 \\
\hline $\mathrm{SO}_{4}{ }^{--}$ & 0.002 \\
\hline $\mathrm{CO}_{3}{ }^{2-}$ & 0.072 \\
\hline $\mathrm{PO}_{4}{ }^{3-}$ & 0.003 \\
\hline $\mathrm{F}^{-}$ & $<0.01$ \\
\hline $\mathrm{Cl}^{-}$ & 0.012 \\
\hline $\mathrm{Oxalate}^{-}$ & $<0.01$ \\
\hline $\mathrm{Formate}^{-}$ & $<0.02$ \\
\hline
\end{tabular}

\begin{tabular}{|l|l|}
\hline Component & Concentration $(\mathbf{m g} / \mathbf{L})$ \\
\hline $\mathrm{Ag}$ & $<6$ \\
\hline $\mathrm{Ba}$ & $<3$ \\
\hline $\mathrm{Ca}$ & $<20$ \\
\hline $\mathrm{Cd}$ & $<2$ \\
\hline $\mathrm{Cr}$ & 31 \\
\hline $\mathrm{Mg}$ & $<1$ \\
\hline $\mathrm{Pb}$ & $<30$ \\
\hline $\mathrm{Sr}$ & 0.048 \\
\hline & \\
\hline $\mathrm{Component}$ & $\begin{array}{l}\text { Concentration } \\
(\mathrm{d} / \mathbf{m} / \mathbf{m L})\end{array}$ \\
\hline $\mathrm{Cs}-137$ & $1.6 \mathrm{E}+09$ \\
\hline $\mathrm{Sr}-90$ & $2.2 \mathrm{E}+05$ \\
\hline $\mathrm{Tc}-99$ & $2.5 \mathrm{E}+05$ \\
\hline $\mathrm{Pu}-238$ & $1.7 \mathrm{E}+03$ \\
\hline $\mathrm{Pu}-239 / 240$ & $<1.2 \mathrm{E} 2$ \\
\hline & \\
\hline Component \\
(mass number)*
\end{tabular}

Table shows composition after dilution with $2 \mathrm{M} \mathrm{NaOH}$ to achieve $5.6 \mathrm{M} \mathrm{Na}^{+}$.

Analyses performed on unfiltered samples.

*Results reflect total mass for the indicated mass number. For example, M-238 includes $\mathrm{U}-238$ and $\mathrm{Pu}-238$. 


\section{Contactor Physical Configuration}

The process equipment used for these tests included 33 stages of 316 stainless steel, 2-cm annular centrifugal contactors designed and fabricated by Argonne National Laboratory. The contactors were grouped into one solvent wash stage, 15 extraction stages, two scrub stages, and 15 strip stages in a two-tiered configuration. Figure 1 shows a schematic diagram of the system and includes indication of the sampling points. Figure 2 shows the apparatus as it appeared in a non-radioactive laboratory prior to the test.

\section{Experimental Operations and Sampling Plan}

Researchers operated the solvent extraction contactor apparatus following a Waste Processing Technology Section operating procedure. ${ }^{5}$ The sampling plan developed prior to the test was documented previously. ${ }^{1}$ A Timekeeper Run Sheet containing sample identification, sampling location, and timing was prepared as described in the test procedure and sampling plan. Samples were taken by placing sample containers at the outlet points of the continuously flowing streams. Samples of the solvent feed stream were not taken during the test (as specified in the sampling plan) to avoid disrupting the hydraulic flow conditions.

During simulant tests, samples were initially taken in 20 -mL glass vials with Teflon ${ }^{\mathrm{TM}}$ lined screw-on caps. Several vials containing the waste raffinate samples leaked because this particular stream caused the caps to loosen. For the radioactive waste test, the sample containers for this stream were changed to $35-\mathrm{mL}$ polyethylene bottles. The following sections summarize the analytical methods that supported each objective.

\section{Solvent Entrainment and Degradation}

Solvent or aqueous entrainment was measured primarily by the decanters. In addition, periodic samples of the effluent from the decanters were analyzed for Cs7SB modifier and BOBCalixC6 by high performance liquid chromatography (HPLC). Due to the high Cs-137 activity of the strip raffinate samples in the radioactive waste test, they were extracted with dodecane ( $5 \mathrm{~mL}$ of dodecane to $5 \mathrm{~mL}$ of sample) in the Shielded Cells and the extract removed for analysis.

Solvent degradation was measured using solvent samples taken periodically during the test. Cs7SB modifier and BOBCalixC6 were measured by HPLC. Trioctylamine was measured by a gas chromatography-mass spectroscopy (GC-MS) instrument. 
WSRC-TR-2001-00372, Rev. 0

Page 10 of 21

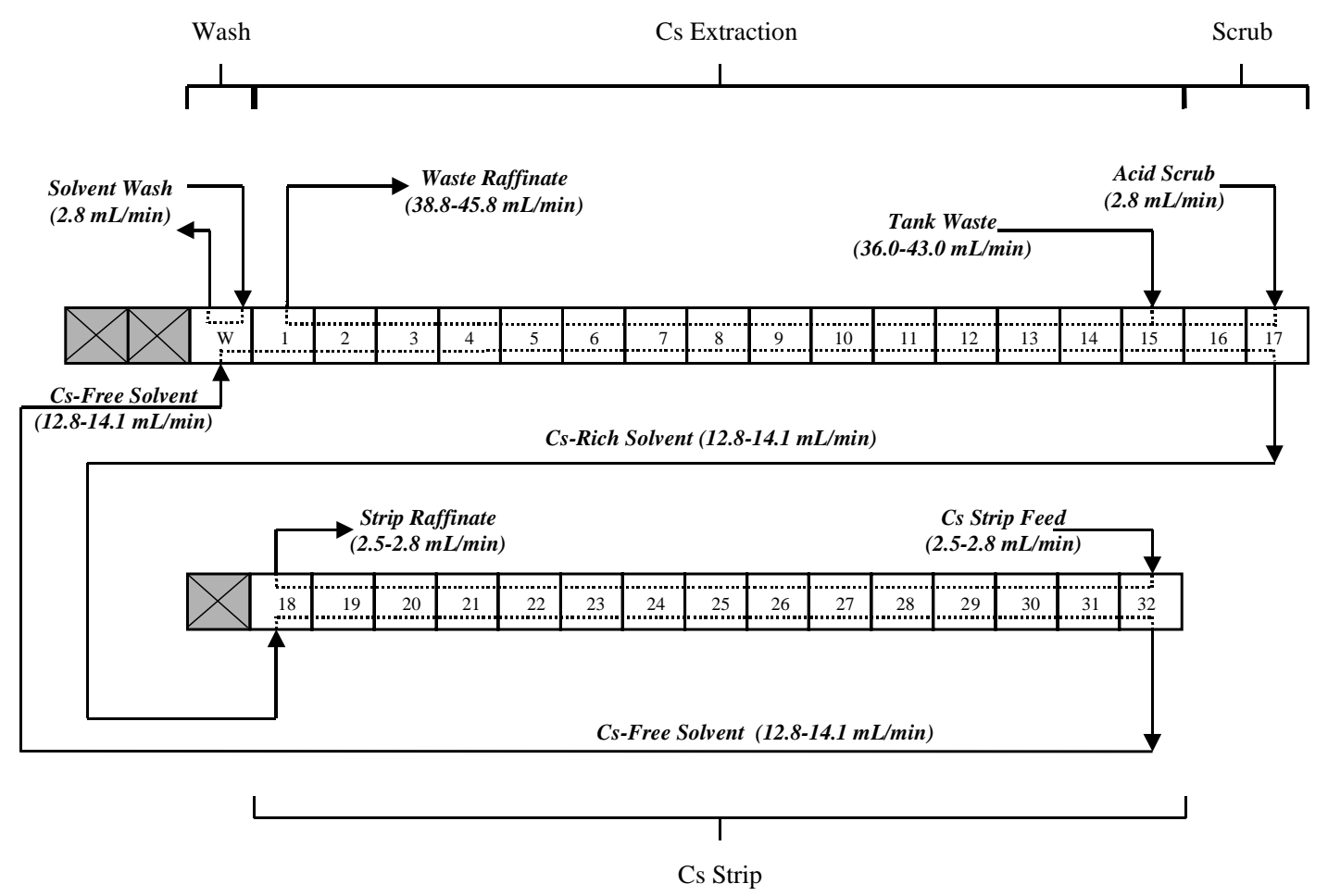

Figure 1. Flow diagram and sampling points

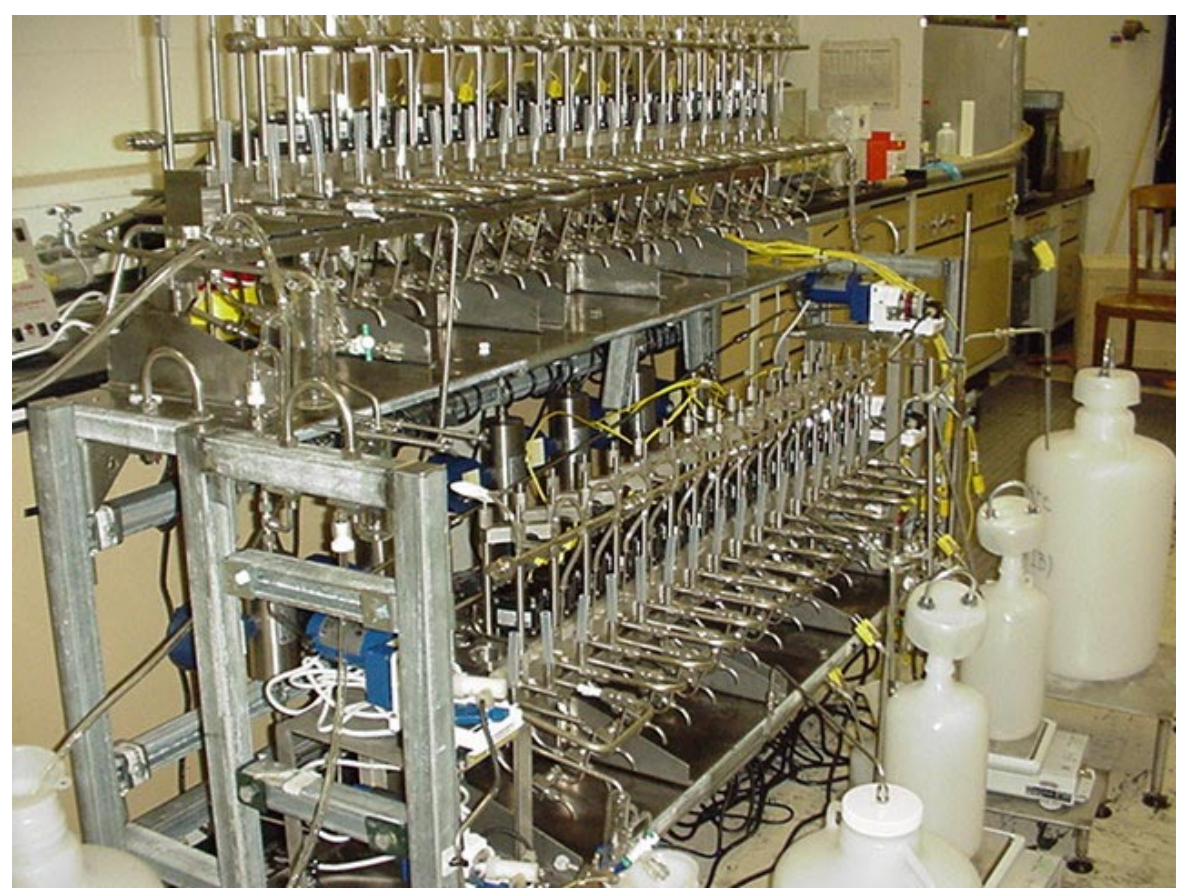

Figure 2. Contactor apparatus and feed tanks 


\section{Minor Components}

Minor inorganic components in the aqueous streams were measured by inductively coupled plasma emission spectroscopy (ICP-ES), inductively coupled plasma mass spectroscopy (ICP-MS), and atomic adsorption (AA) methods. Highly radioactive samples from the radioactive waste test were treated with ammonium molybdophosphate hydrate on acrylonitrile polymer (AMP-PAN sorbent) to reduce the Cs-137 activity. ${ }^{6}$ The sample $(20 \mathrm{~mL})$ was stirred with AMP-PAN sorbent $(2 \mathrm{~g})$ at ambient temperature for 2 hours and filtered using a 0.45 micron Nylon disposable filter.

Chromatographic methods measure concentrations of minor organic components. Tri- $n$ butyl phosphate (TBP), trimethylamine (TMA), trioctylamine (TOA), dioctylamine (DOA), 4-sec-butylphenol (SBP), and $n$-butanol were measured by GC-MS. Di- $n$-butyl phosphate was measured by ion chromatography.

Trace elements in the solvent were measured using ICP-ES and ICP-MS following digestion of the sample. Samples were digested by wet oxidation using concentrated nitric acid at $155^{\circ} \mathrm{C}$ in a Teflon ${ }^{\mathrm{TM}}$ lined Parr bomb.

\section{Analytical Methods}

GC-MS

GCMS methods were used to analyze for volatile organic components (VOCs, such as $n$-butanol) and semivolatile organic compounds (SVOCs, such as TMA, TOA, DOA, $\mathrm{TBP}$, and SBP). Analysis used selected ion monitoring of the target compounds.

Aqueous samples for VOC analysis were concentrated by an OI Analytical Model 4460A Dynamic Headspace Concentrator (purge and trap), using a three-stage trap $(10 \mathrm{~cm}$ Carbopack B, $6 \mathrm{~cm}$ Carboxen 1000, and $1 \mathrm{~cm}$ Carboxen 1001). Aqueous samples for SVOC analysis were prepared by adjusting $\mathrm{pH}$ to neutral followed by extraction with methylene chloride. Organic matrix samples were diluted in methylene chloride or isopropanol.

VOC separations used a Hewlett Packard Model 5890 Series II gas chromatograph with a $60 \mathrm{~m} \times 0.75 \mathrm{~mm}$ VOCOL glass capillary column with 3 um film thickness. Quantitation used a Hewlett Packard Model 5971 quadrupole mass spectrometer. A glass jet separator was inline ahead of the mass spectrometer inlet.

SVOC separations used a Hewlett Packard 6890 gas chromatograph, equipped with a $30 \mathrm{~m}$ DB-5 column, with $0.25 \mathrm{~mm}$ diameter and 0.25 um film thickness. Quantitation used a Hewlett Packard 5973 mass selective detector. Researchers used perfluorotributylamine to confirm the mass spectrometer tuning within 24 hours prior to each measurement. 
HPLC

Aqueous samples were extracted three times in the sampling vial with methylene chloride, evaporated to dryness at ambient temperature, and the residue taken up in chloroform for analysis. Solvent samples were diluted 100-fold in chloroform. Dodecane extracts of aqueous samples were analyzed without dilution. Extraction efficiencies measured on simulated waste solutions exceeded $90 \%$ and no corrections were applied to the radioactive waste results. The BOBCalixC6 and Cs7SB modifier were analyzed on a Hewlett-Packard 1090 HPLC using a 8x300 mm Shodex K-801GPC column, a chloroform mobile phase at $1 \mathrm{~mL} / \mathrm{min}$, and UV detection at $280 \mathrm{~nm}$. Each analysis requires 10 minutes with $\mathrm{BOBCalixC6}$ eluting first at 5.7 minutes and $\mathrm{Cs} 7 \mathrm{SB}$ modifier at 6.8 minutes.

ICP-ES

ICP-ES measured Al, B, Ba, Ca, Cd, Co, Cr, Cu, Fe, La, Li, Mg, Mn, Mo, Na, Ni, P, Pb, $\mathrm{Si}, \mathrm{Sn}, \mathrm{Sr}, \mathrm{Ti}, \mathrm{V}, \mathrm{Zn}$, and $\mathrm{Zr}$. Aqueous samples were diluted to $<250 \mathrm{ppm} \mathrm{Na}$ and injected into an ARL Model 3580 ICP-ES instrument.

ICP-MS

ICP-MS measured actinide and fission product isotopes. Aqueous samples were diluted to $<0.5 \mathrm{M} \mathrm{Na}$ and injected into a VG Plasma Quad II ICP-MS instrument. 


\section{RESULTS AND DISCUSSION}

\section{Organic Compounds in the Tank 37H/44F Composite Waste}

Researchers analyzed for several organic compounds that are potentially present in SRS high-level waste or that might result from contact with the CSSX solvent system. Table III lists results for these compounds. Due to the high Cs-137 activity in the waste, it had to be diluted 100-fold to reduce the radiation dose rate to acceptable levels for the hand contact needed for analysis. This points out the need for sample preparation methods to improve the lower detection limits. Methods that remove cesium without affecting the organic compounds or sample extraction methods for the Shielded Cells facility are likely more feasible than improving the lower detection limit of the instrumentation.

A non-radioactive simulant solution was analyzed as a blank solution along with the waste solution. None of the organic compounds were found above detection limits in the blank.

\section{Solvent Entrainment}

Second phase carryover is defined as an unwanted phase observed exiting in a primary product stream (e.g. the organic solvent entrained in the decontaminated waste stream). The test objective was to maintain second phase carryover below 1.0 vol \%. Excessive second phase carryover of organic in aqueous streams is indicative of poor hydraulic performance and can lead to large losses of valuable solvent.

Second-phase carryover reported previously derived from measurements of the volume of solvent collected in the process decanters (Table IV). ${ }^{1}$ The portion of the second phase that is dissolved or suspended in the overflow from the decanters is not included in this measurement. Therefore, samples of the aqueous overflow streams (decontaminated salt solution and strip effluent) were analyzed for solvent components (Cs7SB modifier and

Table III. Organic Compounds in the Tank 37H/44F Composite Sample (at 5.6 M $\mathrm{Na}^{+}$)

\begin{tabular}{ll} 
Compound & Conce \\
\cline { 2 - 2 } Trimethylamine & $<1000$ \\
Trioctylamine & $<1000$ \\
Dioctylamine & $<1000$ \\
sec-Butylphenol & $<1000$ \\
Tri- $n$-butyl phosphate & $<1000$ \\
$n$-Butanol & $<1000$ \\
Dibutyl phosphate & $<1000$
\end{tabular}


WSRC-TR-2001-00372, Rev. 0

Page 14 of 21

Table IV. Solvent Entrainment Estimated From Decanter Observations

Process Stream

Solvent in

decontaminated

waste

Solvent in strip

effluent

Solvent in

solvent wash

effluent
Decanter Observations

$2.5 \mathrm{~mL}$ of a total flow of $30,000 \mathrm{~mL}(0.01 \%)$ for the first 14

hours

$19 \mathrm{~mL}$ of a total flow of $9,000 \mathrm{~mL}(0.21 \%)$

no measurable carryover for the first 27 hours

$12.5 \mathrm{~mL}$ of a total flow of $3,400 \mathrm{~mL}(0.37 \%)$ for the final 20

hours

BOBcalixC6) to determine the amount of carryover missed by the decanter measurements. Table $\mathrm{V}$ lists the results of the analyses and calculated carryover. The calculation is based on the Cs7SB modifier concentrations and the relative flow rates of the two phases. The calculation assumes the Cs7SB modifier concentration is due to physical carryover rather than solubility. This assumption is supported by the observation that the solvent composition at the beginning and end of the test did not differ significantly.

For the decontaminated waste stream, carryover from the decanter was not detected except in the last sample. Based on the detection limit for the analytical method, there was less than $0.07 \%$ carryover during most of the test, or slightly less than estimated from the decanter measurements. The total remains much less than the target of $<1 \%$. A diluted waste sample that had not contacted solvent was included as a blank and analyzed at the same time as the decontaminated waste. The blank showed $8 \mathrm{mg} / \mathrm{L}$ of Cs7SB modifier. This may have resulted from cross contamination of samples during handling or analysis and points out the need for careful handling in future tests.

The aqueous strip effluent $\left(0.0010 \mathrm{M} \mathrm{HNO}_{3}\right)$ also showed less than detectable amounts of BOBCalixC6 and Cs7SB modifier. The estimated maximum carryover in this stream was $0.0006 \%$, or less than $0.3 \%$ of the amount estimated from the decanter measurements.

The solvent wash effluent $(0.010 \mathrm{M} \mathrm{NaOH})$ contained measurable amounts of Cs7SB modifier. The calculated carryover varied between 0.002 and $0.007 \%$. These values are much less than the target of $<1 \%$ and insignificant compared to the amount estimated from the decanter measurements in the final 20 hours of the test $(0.37 \%)$. The estimates exceed the "none detectable" result from the decanter observations during the initial 27 hours of the test. The presence of solvent components in the dilute hydroxide stream is consistent with observations of slow-breaking emulsions and low dispersion numbers for the combination of solvent system and wash solution. The Tank Focus Area Salt Processing Project research and development plan ${ }^{7}$ includes additional tests to optimize the $\mathrm{NaOH}$ concentration (for improved phase separation) in the solvent washing step. 
Table V. BOBCalixC6 and Cs7SB Modifier Concentrations in Process Streams

\begin{tabular}{|c|c|c|c|c|}
\hline Aqueous Stream & Elapsed & Concentration & $(\mathrm{mg} / \mathrm{L})$ & Carryove \\
\hline & $\underline{\text { Time (h) }}$ & BOBCalixC6 & Cs7SB Modif & fier $(\%)^{*}$ \\
\hline Decontaminated waste & 0 & $<4$ & $<4$ & -- \\
\hline & 12 & $<4$ & $<4$ & $<.007$ \\
\hline & 24 & $<4$ & $<4$ & $<.007$ \\
\hline & 36 & $<4$ & $<4$ & $<.007$ \\
\hline & 48 & $<4$ & 21 & 0.035 \\
\hline Strip effluent & 0 & $<4$ & $<4$ & -- \\
\hline & 12 & $<4$ & $<4$ & $<.0006$ \\
\hline & 24 & $<4$ & $<4$ & $<.0006$ \\
\hline & 36 & $<4$ & $<4$ & $<.0006$ \\
\hline & 48 & $<4$ & $<4$ & $<.0006$ \\
\hline Solvent wash effluent & 0 & $<4$ & $<4$ & -- \\
\hline & 12 & $<4$ & 16 & 0.002 \\
\hline & 24 & $<4$ & 47 & 0.006 \\
\hline & 36 & $<4$ & 13 & 0.002 \\
\hline & 48 & $<4$ & 54 & 0.007 \\
\hline
\end{tabular}

* Percentage of the organic phase carried over in the aqueous phase.

\section{Solvent Composition Changes}

The solvent reservoir was sampled at the beginning and end of the 48 hour test. The solvent flow rate and test duration corresponded to 25 turnovers of the solvent. The samples were analyzed for the three solvent components, BOBCalixC6, Cs7SB modifier, and trioctylamine. Table VI lists the results of the analyses. No significant change was observed between the initial and final samples. The consistency of the BOBCalixC6 and Cs7SB modifier concentrations suggest that neither one is selectively removed from the solvent due to solubility in the aqueous streams.

Trioctylamine was not detected in either solvent sample during the initial attempt. Higher than expected amounts were found in repeat analyses of the same samples. Despite the questionable reproducibility and possible high bias of the analytical method, the slight drop in TOA concentration during the test may be real. Further work is suggested to improve and verify the accuracy and precision of this analysis so that the potential loss of TOA can be studied in future tests. 
TABLE VI. Solvent Composition Changes

Sample

Initial

Final

Theoretical*
Concentration $(\mathrm{mg} / \mathrm{L})$

BOBCalixC6 Cs7SB Modifier $\quad \underline{\text { Trioctylamine }} *$ *

$13,000 \quad 171,000$

$12,300 \quad 171,300$

$<10, \quad 450$

$<10, \quad 400$

340

*Based on 0.010 M BOBCalix C6, 0.50 M Cs7SB modifier, and 0.001 M trioctylamine. **Initial results indicated TOA $<10 \mathrm{mg} / \mathrm{L}$ but repeat analyses showed expected amounts.

\section{Minor Organic Components}

Table VII shows results of analyses for minor organic compounds (TMA, TOA, DOA, TBP, DBP, $n$-butanol, and sec-butylphenol) in the four process streams.

Decontaminated waste solution was analyzed for organic compounds that may have been in the waste originally or arose from solvent decomposition during the test. The detection limits on the decontaminated waste were lower than on the original waste because no dilution was required for safe handling. Samples taken at 12, 24, 36, and 48 hours were analyzed for DBP. A composite of hourly samples was analyzed for DBP and other compounds. None of the targeted organic compounds were detected.

Initial and final samples of solvent were analyzed for minor organic compounds. Although it was not detectable in the waste, $n$-butanol (a decomposition of product of tributyl phosphate) was found in the solvent before and after use. Since n-butanol is highly unlikely in unused solvent, this result suggests a problem with analytical method

\section{TABLE VII. Minor Organic Compounds}

\section{Compound}

Trimethylamine

Trioctylamine

Dioctylamine

Tributyl phosphate

Dibutyl phosphate

n-Butanol

sec-Butylphenol

\begin{tabular}{|c|}
\hline $\begin{array}{c}\text { Decontam } \\
\text { Waste }\end{array}$ \\
\hline$<10$ \\
\hline$<10$ \\
\hline$<10$ \\
\hline$<10$ \\
\hline$<10$ \\
\hline$<10$ \\
\hline$<10$ \\
\hline
\end{tabular}

*See Table VI for results.
Concentration (mg/L)

$$
\text { Solvent Strip Wash }
$$

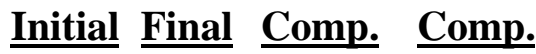

$<10<10 \quad \frac{10}{33}$

$* \quad * \quad<10<10$

$<10<10<10<10$

$<10<10<10<10$

$<10<10<10<10$

$360 \quad 96<10<10$

$<10<10<10<10$ 
(VOA by GC-MS) rather than accumulation of $n$-butanol from the waste. None of the other targeted organic compounds were detected.

The strip effluent stream was sampled after 12, 24, 26, 48 hours and a composite sample was taken from the tank of spent strip solution. The 12-hour interval samples were analyzed for dibutyl phosphate and the composite sample was analyzed for dibutyl phosphate and other targeted organics. None of the targeted organics were found above detection limits in any of the samples.

A sample of the accumulated solvent wash effluent was taken at the end of the test and analyzed for the targeted minor organic compounds. Trimethylamine was detected at 33 $\mathrm{mg} / \mathrm{L}$ and all of the other targeted organics were below detection limits. The presence of trimethylamine in this sample is unexpected since, if trimethylamine was present in the waste and was stripped by the solvent, then it should be removed by the acid scrub and strip solutions rather than by the alkaline wash solution. This result is likely a false positive from contamination of the sample or analysis error. No action should be taken until future testing verifies this result. A blank sample of solvent wash solution taken prior to use showed $28 \mathrm{mg} / \mathrm{L} \mathrm{sec-butylphenol.} \mathrm{Again,} \mathrm{the} \mathrm{result} \mathrm{is} \mathrm{likely} \mathrm{a} \mathrm{false} \mathrm{positive}$ due to sample contamination or analysis error.

\section{Minor Inorganic Components}

The solvent, strip effluent, and solvent wash effluent were analyzed for minor inorganic components by ICP-ES and ICP-MS analyses. Table VIII lists the results.

The initial and final solvent samples were digested prior to analysis. Most elements were below detection limits of the analytical methods and no elements appeared to accumulate in the solvent during the 48 hour test. The few elements that were above detection limit in the initial sample decreased by the end of the test. This result shows that the scrubbing, stripping, and washing keeps the solvent clean of many inorganic impurities.

The composite of hourly strip effluent samples was treated with AMP-PAN sorbent (ammonium molybdophosphate hydrate on acrylonitrile polymer) to remove Cs-137. The treated solution was analyzed without dilution. The Mo, Na, and $\mathrm{P}$ are likely due the to AMP-PAN treatment. Small amounts of potassium $(1.33 \mathrm{mg} / \mathrm{L})$ were detected as expected since $\mathrm{K}$ is extracted with the cesium. The scrub solution removes most of the $\mathrm{K}$, but small amount of residual $\mathrm{K}$ appears to be removed by the strip solution.

The $0.010 \mathrm{M} \mathrm{NaOH}$ solvent wash solutions contained minor amounts of several elements Initially, sodium, aluminum, boron, and silicon were found at significant levels, but they decreased during use. Their origin is likely the sodium hydroxide used to prepare the $\mathrm{NaOH}$ solution and leaching of the glass vials in which they were stored. The majority of the sodium ( $223 \mathrm{mg} / \mathrm{L}$ of the $269 \mathrm{mg} / \mathrm{L}$ found) is due to the sodium hydroxide used to prepare the solution. 
TABLE VIII. Minor Inorganic Components

\section{Component}

Al

B

$\mathrm{Ba}$

$\mathrm{Ca}$

$\mathrm{Cd}$

$\mathrm{Co}$

$\mathrm{Cr}$

$\mathrm{Cu}$

$\mathrm{Fe}$

$\mathrm{La}$

$\mathrm{Li}$

$\mathrm{Mg}$

$\mathrm{Mn}$

Mo

$\mathrm{Na}$

$\mathrm{Ni}$

$\mathrm{P}$

$\mathrm{Pb}$

$\mathrm{Si}$

$\mathrm{Sn}$

$\mathrm{Sr}$

$\mathrm{Ti}$

$\mathrm{V}$

$\mathrm{Zn}$

$\mathrm{Zr}$

\section{Solvent*}

$\underline{\text { Initial Final }}$

$20<10$

$<2<2$

$<2<2$

$<.7<.8$

$<1.4<.8$

$<2<2$

$<6<5$

$34 \quad 40$

$70 \quad 30$

$<6<6$

$<2<2$

$130 \quad 40$

$<.7<.8$

$<2<2$

$16 \quad 50$

$12 \quad 10$

$<20<20$

$<30<25$

$300 \quad 150$

$<10<10$

$<.7<.8$

$<.7<.8$

$<2<2$

34

$<2<2$

$<4<1$

K (by AA)

Tc (by ICP-MS) <.00001 $\quad 0.0005$

Formate

Nitrate

Nitrite

Phosphate

Sulfate

Fluoride

Chloride

\section{Concentration (mg/L)}

\section{Strip Effluent}

$\underline{\text { Composite } * *}$

1.0

7.2

$<.03$

6.6

$<.02$

0.035

$<.09$

0.05

0.06

$<.1$

$<.03$

1.5

0.03

25.

18.

$<.09$

2.8

$<.5$

18.

$<.16$

0.03

0.013

$<.03$

0.04

0.04

1.33

0.008

$<.00003$

7

440

$<10$

$<10$

$<5$

9

12
Solvent Wash

Initial Final

$\begin{array}{ll}3.2 & 0.5\end{array}$

$6.3 \quad 4.9$

$<.03<.03$

$<.01<.01$

$0.02<.02$

$0.04<.03$

$<.09<.09$

$0.04<.03$

$0.09<.04$

$<.1<.1$

$<.03<.03$

$0.10 \quad 0.05$

$<.01<.01$

$0.05<.03$

$270 \quad 250$

$<.09<.09$

$0.69<.35$

$<.5<.5$

$27 \quad 11$

$0.24<.16$

$<.01<.01$

$0.04<.01$

$0.07<.03$

$<.03<.03$

$0.07<.03$

0.53

$<10$

160

$<10$

$<10$

$<5$

$<2$

$<2$

* Solvent samples were digested prior to analysis.

**Sample was treated with AMP-PAN sorbent to remove Cs-137 prior to analysis. 
The concentrations of uranium and plutonium in the waste were low and near the detection limits of the analytical methods (Table IX). The limited results for uranium do not indicate that it concentrates in the solvent or strip effluent. The slight increase between the initial and final solvent samples is likely within the analytical error (compare to the strip effluent result). However, the increase could also indicate that the system did not reach steady state during the test. All plutonium measurements were below detection limits.

TABLE IX. Uranium Concentrations in Process Streams

$\underline{\text { Component }}$

Concentration $(\mathbf{m g} / \mathbf{L})$

\begin{tabular}{|c|c|c|}
\hline & & Solvent \\
\hline M/Thif wase & Ct $t$ & al $\mathrm{Fi}$ \\
\hline
\end{tabular}

Mass-238 


\section{CONCLUSIONS}

The CSSX process flowsheet for the decontamination of high-level waste was demonstrated in a 33-stage, 2-cm contactor apparatus using actual Tank 37H/44F composite high-level waste in a 48-hour test. Results of analyses for organic compounds and minor components in the various process streams do not indicate any problems with the viability of the process. Conclusions from this work include the following.

- The Tank 37H/44F composite radioactive waste feed contained less than $1000 \mathrm{mg} / \mathrm{L}$ of the organic compounds measured.

- Detection limits were high $(1000 \mathrm{mg} / \mathrm{L})$ due to the required 100 -fold dilution for safe handling outside of a shielded facility.

- Aqueous streams exiting decanters showed only minimal solvent carryover and solubility.

- This result confirms previous estimates from the decanter measurements.

- Waste components were not concentrated in the spent strip solution, thus reducing concerns about minor components going to the DWPF.

- Uranium, Tc-99, and K were not concentrated in the strip solution.

- Potential organic compounds from the waste were not detected $(<10 \mathrm{mg} / \mathrm{L})$.

- The solvent system changed very little during the 25 turnovers experienced in the test.

- The concentrations of major solvent components (extractant and modifier) did not change significantly.

- The solvent did not concentrate uranium.

\section{FUTURE WORK}

Improved analytical capabilities are needed for future work on the CSSX process with radioactive waste. The following areas of development are recommended.

- Develop more sensitive methods for organic compounds in actual waste and radioactive process streams.

- Due to the high activity of the samples, they must be diluted prior to handling outside of a shielded facility. Methods of reducing Cs-137 activity without affecting organic concentrations are needed.

- Develop more sensitive methods for minor components in solvent samples.

- Digestion and dilution of the organic samples reduces the sensitivity and potentially adds impurities. Direct injection of solvent into a GC-MS is recommended. 


\section{REFERENCES}

1. S. G. Campbell, M. W. Geeting, C. W. Kennell, J. D. Law, R. A. Leonard, M. A. Norato, R. A. Pierce, T. A Todd, D. D. Walker, and W. R. Wilmarth, "Demonstration of Caustic-Side Solvent Extraction with Savannah River Site High-Level Waste," WSRCTR-2001-0023, Rev. 0, April 19, 2001.

2. P. V. Bonnesen, L. H. Delmau, T. J. Haverlock, and B. A. Moyer, "Alkaline-Side Extraction of Cesium from Savannah River Tank Waste Using a Calixarene-Crown Ether Extractant," ORNL/TM-13704, December 1998.

3. R. A. Leonard, S. B. Aase, H. A. Arafat, C. Conner, J. R. Falkenberg, and G. F. Vandegrift, "Proof-of-Concept Flowsheet Tests for Caustic-Side Solvent Extraction of Cesium from Tank Waste," ANL-00/30, November 2000.

4. R. A. Leonard, S. B. Aase, H. A. Arafat, D. B. Chamberlain, C. Conner, M. C. Regalbuto, and G. F. Vandegrift, "Interim Report On a Multi-Day Test of the CausticSide Solvent Extraction Flowsheet for Cesium Removal from a Simulated SRS Tank Waste," ANL-01/10, April 2001.

5. D. D. Walker, "CSSX Contactor Operation (U)," WSRC L12.1, Procedure IWT-OP136, Rev. 1, March 20, 2001.

6. F. Sebesta and V. Stefula, J. Radioanalytical and Nuclear Chemistry, Articles, 140, 15(1990). 